\title{
Leaf breakdown and invertebrate colonization of Eucalyptus grandis (Myrtaceae) and Hirtella glandulosa (Chrysobalanaceae) in two Neotropical lakes
}

\author{
Decomposição e colonização de invertebrados em folhas de \\ Eucalyptus grandis (Myrtaceae) and Hirtella glandulosa \\ (Chrysobalanaceae) em dois lagos Neotropicais
}

Renan de Souza Rezende ${ }^{1}$, José Francisco Gonçalves Jr. ${ }^{1}$ and Mauricio Mello Petrucio ${ }^{2}$

${ }^{1}$ Departamento de Ecologia, Instituto de Biologia - IB, Universidade de Brasília - UnB, CEP 70910-900, Brasília, DF, Brazil

e-mail: renanrezende30@gmail.com, jfunior@icb.ufmg.br

${ }^{2}$ Departamento de Ecologia e Zoologia, Centro de Ciências Biológicas,

Universidade Federal de Santa Catarina - UFSC, Campus Universitário, Bairro Trindade, CEP 88040-970, Florianópolis, SC, Brazil e-mail: petrucio@ccb.ufsc.br

\begin{abstract}
Aim: This study compared the leaf breakdown of Eucalyptus grandis Hill ex. Maiden (an exotic species) and Hyrtella glandulosa Spreng. (a native species), in order to assess the role of invertebrates in decomposition in two tropical lakes (Aguapé and Barra) of the Rio Doce State Park in Southeast Brazil, receiving allochthonous organic matter during the dry and rainy seasons; Methods: Senescent leaves $(4 \pm 0.1 \mathrm{~g}$ dry weight) were placed in litter bags $(30 \times 30 \mathrm{~cm}, 5 \mathrm{~mm}$ mesh size $)$ and submerged in the lakes. Replicate bags $(\mathrm{n}=4)$ were then retrieved after 3, 7, 15, 30, 60, 90 and 120 days; Results: The breakdown of $E$. grandis leaves (range $\mathrm{k}=-0.007$ to -0.015 ) was faster than H. glandulosa (range $\mathrm{k}=-0.005$ to -0.008 ). Breakdown rates were higher during the rainy season than the dry season. Leaves of $E$. grandis and $H$. glandulosa did not differ in terms of invertebrate colonization. The highest densities were observed in Aguapé Lake during the rainy season. Taxonomic richness was higher in E. grandis and in Aguapé Lake, but no differences between the rainy and dry seasons were observed. Functional trophic groups differed between leaf types and seasons. Gatherer-collectors and scrapers predominated in E. grandis and in the dry season; Conclusions: The higher breakdown observed in Barra Lake was probably a consequence of the elevated temperatures and the presence of Gastropoda (scrapers). Aquatic invertebrates did not have difficulties in the colonization of exotic leaves (E. grandis) compared with native leaves ( $H$. glandulosa). We observed that in the rainy season, the higher decay rates and density of invertebrate communities, indicating the increased temperatures, nutrient inflow and organic matter brought by the rain, accelerated this process compared with the dry season.
\end{abstract}

Keywords: aquatic, functional trophic groups, Atlantic Rain Forest, silviculture, seasonality.

Resumo: Objetivo: Este estudo comparou a perda de massa foliar de Eucalyptus grandis Hill ex. Maiden (espécie exótica) e Hyrtella glandulosa Spreng. (espécie nativa), e avaliou o papel dos invertebrados no processo de decomposição em dois lagos tropicais (Aguapé e Barra) do Parque Estadual de Rio Doce no Sudeste do Brasil, em matéria orgânica de origem alóctone durante as estaçóes seca e chuvosa; Métodos: Folhas senescentes $(4 \pm 0,1 \mathrm{~g}$ de peso seco) foram colocadas em "litter bags" $(30 \times 30 \mathrm{~cm}$, tamanho da malha de $5 \mathrm{~mm})$ e incubadas nos lagos. As replicas $(n=4)$ foram retiradas após 3, 7, 15, 30, 60, 90 e 120 dias; Resultados: A decomposição das folhas de $E$. grandis $(\mathrm{k}=-0.007$ to -0.015 ) foi mais rápido do que $H$. glandulosa $(\mathrm{k}=-0.005$ to -0.008$)$. As taxas de decomposição foram maiores na estação chuvosa do que na estação seca. As folhas de E. grandis e H. glandulosa não se diferiram quanto a colonização por invertebrados. As maiores densidades foram observadas no lago Aguapé, mas não foram diferentes entre as estaçóes seca e chuvosa. Os grupos funcionais tróficos foram diferentes entre o tipo de folha e estaçóes. Coletores-catadores e raspadores foram predominantes em $E$. grandis na estação seca; Conclusóes: A maior taxa de decomposição observada no lago Barra provavelmente ocorreu em conseqüência das maiores temperaturas e presença de Gastropoda (raspadores). 
Os invertebrados aquáticos não tiveram dificuldades na colonizaçáo de folhas exóticas (E. grandis) comparado com as folhas nativas $(H$. glandulosa). Observou-se na estação chuvosa, as maiores taxas de decomposiçáo e densidade da comunidade de invertebrados, indicando que o aumento de temperatura, entrada de nutrientes e matéria orgânica trazidas pela chuva, aceleram estes processos se comparados a estação seca.

Palavras-chave: aquático, grupo funcional trófico, Floresta Atlântica Chuvosa, silvicultura, sazonalidade.

\section{Introduction}

The breakdown of allochthonous leaf detritus is a fundamental process for the understanding of energy flow and metabolism maintenance in aquatic ecosystems (Benfield, 1997; Wallace and Webster, 1996). This process is influenced by communities of microorganisms and invertebrates (mainly shredders) that transform the coarse particulate organic matter (CPOM) into fine particulate organic matter (FPOM) (Gessner et al., 1999). Shredders have great influence on the decomposition process because they feed directly on plant tissue and therefore have an important role in the conversion of CPOM to FPOM (Cummins et al., 1989; Graça, 2001).

However, some studies have questioned the relative importance of shredders in the processing of plant organic matter in tropical streams (Dobson et al., 2002; Gonçalves Jr. et al., 2006b; 2007). There is evidence that aquatic invertebrates can influence microbial metabolism, being able to speed up or slow down the decomposition process depending on the interaction between the two communities (Webster and Benfield, 1986; Graça, 2001). Predators constitute a good example, because by feeding upon detritivorous organisms they produce a top-down effect in the trophic chain (Wallace et al., 1997; Jonsson et al., 2001). The community of aquatic invertebrate also plays an important role as fundamental links in several food webs, ingesting many species and serving as food for others, such as macroinvertebrates, fish and birds (Nolte, 1986).

The control mechanisms and interactions between communities of microorganisms and aquatic invertebrates in tropical ecosystems in Brazil are still unclear (Moretti et al., 2007b), even though Brazil is considered a mega-diversity country. Thus, scientific efforts intended to better understand the aquatic biodiversity are fundamental to broaden the knowledge of the Neotropical region, in particular the middle portion of the Rio Doce Basin in East of Minas Gerais State, Southeast Brazil (Hotspot/ Atlantic Forest). This part of the basin is heavily affected by human influences, including large areas of degraded pastureland, heavy industries (iron and steel plants and cellulose), and extensive areas planted with Eucalyptus spp. (Petrucio and Barbosa, 2004).

The replacement of areas of native vegetation by plantations of species of Eucalyptus is a successful development of Brazilian forestry, because of the rapid growth and wide applicability of its wood for different purposes (Majer and Recher, 1999). However, this replacement has ecological costs that should be considered for the long-term maintenance of biodiversity. The replacement of native species by exotic ones (e.g. Eucalyptus spp.) can sharply alter the characteristics of the process of decomposition of leaf detritus, and consequently the energy flow and dynamics of organic matter in aquatic ecosystems (Graça et al., 2002). Members of the genus Eucalyptus have low contents of nitrogen, phosphorus and refractory compounds (lignin and hemicelluloses) compared to the native species (Louzada, 1997; Ostrofsky, 1997), and therefore their detritus has less nutritive value for the local biota. Also, the local biota may not be adapted to exploit and colonize this resource, because of the residues of defensive compounds released by the detritus during decomposition (Canhoto and Graça, 1992; 1995).

Compared to lotic systems, the dynamics of coarse detritus decomposition has not received much attention in lakes (Bohman and Herrmann, 2006). Productivity in small lake systems often depends on allochthonous organic inputs, and disturbances affecting detritus subsidies or its processing could potentially influence the ecosystem (Pimentel et al., 2001; Gessner and Chauvet, 2002). Because the importance of allochthonous organic inputs, studies on the interaction between aquatic and terrestrial ecosystems, and the potential effects of replacement of Atlantic Rain Forest vegetation by Eucalyptus grandis on the decomposition rates and invertebrate colonization process, are fundamental for the conservation of aquatic resources and their biological diversity. 
All study was based in following premises: i) In the region we observed the modifications of natural landscape to Eucalyptus plantations which It has high level toxic compounds that could change the ecosystems functioning, because the decrease flowing energy in the food web provoked by low quality and quantity entered of detritus in the lake; ii) The strong effect of seasonality in the region (rainy summer and dry winter) affects physic and chemistry water parameters and input of organic matter. This event, as observed in literature. It is responsible by changes the ecological process, but in the tropical region we found scarce information about its consequence. The hypotheses of this study were: i) invertebrates will find it more difficult to colonize exotic detritus (Eucalyptus grandis Hill ex. Maiden) compared to native-species detritus (Hyrtella glandulosa Spreng); ii) The rates of decomposition and colonization by invertebrates will be higher during the rainy season, because increase of nutrients carried by rains and elevate temperature. Together they provoke a synergic amplification of metabolism on communities during the summer. According to these hypotheses, the following objectives were established. To study two lakes in the same time, seasonal period and detritus to eliminate specific characteristic of process into system; to evaluate the decay rates and invertebrate colonization of leaves of $E$. grandis and H. glandulosa in Aguapé and Barra lakes.

\section{Study area}

We studied two lakes because Barra and Aguapé lakes are situated on the southern boundary of the Rio Doce State Park in Southeast Brazil, an Atlantic Rain Forest conservation unit (Figure 1). The park area (ca. 36,000 ha) is intermingled with a system composed of ca. 150 natural lakes in varying states of evolution, formed between four and ten thousand years ago. Its native vegetation is semideciduous tropical forest, composed of woody and arboreal species that reach heights of 30 to $40 \mathrm{~m}$, and large numbers of vines and epiphytes.

The climate of the region is humid tropical with a unimodal pluviometric regime. Annual rainfall ranges from 1000 to $1200 \mathrm{~mm}$. According to INMET (Brazilian National Institute of Meteorology), March is the end of summer (rainy season, mean air temperature $25^{\circ} \mathrm{C}$, precipitation $200 \mathrm{~mm}$ ); June is the middle of winter (dry season, mean air temperature $20{ }^{\circ} \mathrm{C}$, cumulative precipitation $20 \mathrm{~mm}$ ); and September is the
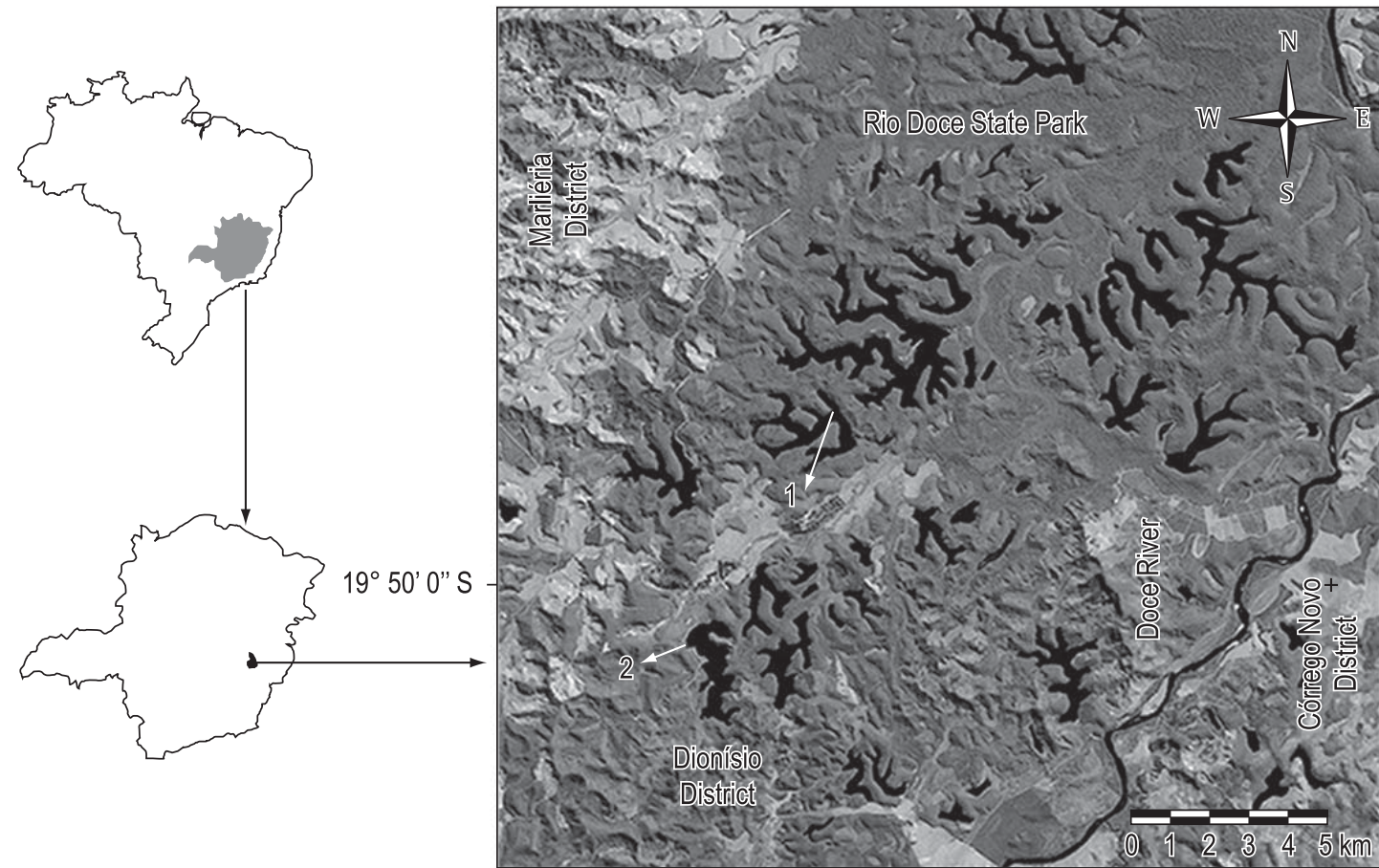

$42^{\circ} 40^{\prime} 0^{\prime \prime} \mathrm{W}$

$42^{\circ} 30^{\prime} 0^{\prime \prime} \mathrm{W}$

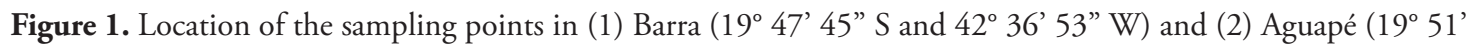
$32^{\prime \prime} \mathrm{S}$ and $\left.42^{\circ} 38^{\prime} 32^{\prime \prime} \mathrm{W}\right)$ lakes in the middle of Rio Doce basin (Minas Gerais, Southeast, Brazil). 
beginning of the rainy season (mean air temperature $23^{\circ} \mathrm{C}$, precipitation $80 \mathrm{~mm}$ ).

Barra Lake is oligotrophic, shallow (maximum depth $10 \mathrm{~m}$ ), and relatively less influenced by human actions; it is surrounded by an abandoned Eucalyptus plantation and naturally regenerating secondary Atlantic Forest (Petrucio et al., 2006). Aguapé Lake is meso-oligotrophic, shallow (maximum depth $10 \mathrm{~m}$ ), has large Eucalyptus plantations in its surroundings, and is the headquarters of a local fishing club, thus being more highly impacted. Domestic effluents were discharged into this lake in the past 30 years; however, this activity was suspended eight years ago. Abiotic parameters of the water of these lakes are shown in Table 1.

\section{Material and Methods}

The detritus used in this study was composed of senescent leaves of the exotic species (Eucalyptus grandis Hill ex. Maiden) and the most common native species around the lakes (Hyrtella glandulosa Spreng). E. grandis and $H$. glandulosa leaves were weighed ( $4 \pm 0.1 \mathrm{~g}$ wet weight) and placed in individual litter bags $(30 \times 30 \mathrm{~cm}$ with $5 \mathrm{~mm}$ mesh size). The litter bags were placed in a row, tied to each other about $20 \mathrm{~cm}$ of distance, and immersed $10 \mathrm{~cm}$ in the littoral zone near the bottom, in areas with no aquatic vegetation, about $1.5 \mathrm{~m}$ from the shoreline and $1 \mathrm{~m}$ deep. The bottom sediments of both lakes are composed basically of sand with a small amount of organic matter. The bags were installed in the lakes during two seasonal periods: dry period (June to September/05) and rainy period (October/05 to January/06). Four litter bags of each species were removed from the lakes after 3, $7,15,30,60,90$, and 120 days, for a total of $56 \mathrm{~L}$ bags in each lake. To estimate the initial oven-dried weight for the leaves used in the experiment, a linear regression of dry weight versus wet weight was calculated for extra samples of each species.

After each immersion period, the litter bags were removed and the detritus was placed in plastic bags and transported to the laboratory in insulated boxes. The leaves were placed in trays and washed with running filtered $(140-\mu \mathrm{m}$ mesh sieve) water.
Five leaves from each litter bag were randomly selected. Discs of ca. $0.04 \mathrm{~g}$ were removed from each leaf in order to determine the ash-free dry weight, calculated after incineration at $550{ }^{\circ} \mathrm{C}$ for four hours. To determine the dry weight, leaves were placed in trays and dried in an oven at $60{ }^{\circ} \mathrm{C}$ for 72 hours. The decay rate $(\mathrm{k})$ was calculated using the negative exponential model $\mathrm{W}_{\mathrm{t}}=\mathrm{W}_{0} \mathrm{e}^{-\mathrm{kt}}$.

The retrieved material was placed in a container with a $70 \%$ ethanol solution to fix and preserve the invertebrates. In the laboratory, the specimens were identified until family level (Pérez, 1988; Merritt and Cummins, 1996) and counted with the aid of a stereomicroscope $(20 \times)$.

The differences between decay rates of the detritus in the two lakes and during the two seasonal periods studied were tested by analyses of covariance (ANCOVA), where the lost mass was the dependent variable, leaf species and seasonal periods were categorical variables, and incubation period was the covariable. The differences between detritus and seasonal periods (categorical variables) versus the invertebrate density and taxonomic richness data (dependent variables) were tested by ANCOVA using incubation period as a covariable. The test was followed by a Tukey test. We used MANOVA to test the differences between detritus, lakes, and seasonal periods (categorical variable) versus the composition of functional trophic groups (dependent variables), followed by Tukey tests (Zar, 1996). All data were ln transformed.

\section{Results}

\subsection{Leaf detritus breakdown}

During the first three days of incubation in the dry period, rapid breakdown of both the E. grandis and $H$. glandulosa detritus was observed. In Aguapé Lake, the remaining percentages of AFDM after three days were 77.47 and $80.34 \%$; while in Barra Lake these percentages were 72.87 and $77.79 \%$, for $E$. grandis and $H$. glandulosa, respectively. During the rainy period in Aguapé Lake, E. grandis showed an accentuated weight loss between the third

Table 1. Abiotic parameters of Aguapé and Barra lakes water at during the two study periods.

\begin{tabular}{|c|c|c|c|c|}
\hline & \multicolumn{2}{|c|}{ Aguapé } & \multicolumn{2}{|c|}{ Barra } \\
\hline & Dry & Rainy & Dry & Rainy \\
\hline $\mathrm{pH}$ & $7.09-7.31$ & $7.21-7.45$ & $6.80-6.96$ & $6.91-7.41$ \\
\hline Electrical conductivity $\left(\mu \mathrm{S} . \mathrm{cm}^{-1}\right)$ & $33.1-35.9$ & $40.8-57.3$ & $27.1-30.4$ & $28.4-43.3$ \\
\hline Alkalinity (mg CaCO3. $\mathrm{L}^{-1}$ ) & $16.5-19.75$ & $18.75-21.0$ & $15.25-17.25$ & $14.5-17.75$ \\
\hline Dissolved oxygen (mg. $\left.\mathrm{L}^{-1}\right)$ & $3.0-4.3$ & $6.2-8.1$ & $2.7-4.0$ & $7.1-8.8$ \\
\hline Temperature $\left({ }^{\circ} \mathrm{C}\right)$ & $24-27$ & $25-30$ & $24-26$ & $29-32$ \\
\hline
\end{tabular}


(91.93\% remaining of AFDM) and the seventh day $(61.96 \%$ remaining of AFDM) of incubation. H. glandulosa lost less weight between the third (95.89\% remaining of AFDM) and the seventh day $(83.32 \%$ remaining of AFDM) of incubation (Figure 2).

The decay rates of $H$. glandulosa in Aguapé and Barra lakes were $\mathrm{k}=-0.007$ and $\mathrm{k}=-0.008$ during the dry period and $\mathrm{k}=-0.007$ and $\mathrm{k}=-0.005$ during the rainy period, respectively. E. grandis showed $\mathrm{k}=-0.007$ and $\mathrm{k}=-0.013$ during the dry period and $\mathrm{k}=-0.010$ and $\mathrm{k}=-0.015$ during the rainy period, in Aguapé and Barra lakes, respectively. The decay rates for both species were faster during the rainy season (ANCOVA, $\mathrm{F}_{(1,192)}=4.031$; $\mathrm{p}=0.046)$. E. grandis leaves decayed faster than H. glandulosa leaves (ANCOVA, $\mathrm{F}_{(1,192)}=52.630$; $\mathrm{p}<0.001$ ) during both seasonal periods (Figure 2). The exception was observed during the dry period in Aguapé Lake, where both species showed similar decay rates $(\mathrm{k}=-0.007)$.

\subsection{Associated invertebrates}

During the study period, densities of invertebrates on the decomposing leaves averaged 30.512 ind. $100 \mathrm{~g}^{-1}$ DW. Chironomidae were the most abundant (22.709 ind.100 $\left.\mathrm{g}^{-1} \mathrm{DW}\right)$, comprising $78 \%$ of the individuals sampled. An exception was Aguapé Lake during the dry period, where Ephemeroptera reached higher densities in the $H$. glandulosa detritus (Table 2). The invertebrate densities did not show significant differences between $E$. grandis and $H$. glandulosa detritus (ANCOVA, $\mathrm{F}_{(1,162)}=2.921 ; \mathrm{p}=0.089$ ). However, invertebrate density was higher during the rainy season (ANCOVA, $F_{(1,162)}=13.576$; $\mathrm{p}<0.001)$.

The number of taxonomic entities (richness hereafter) of aquatic invertebrates was higher in E. grandis detritus (ANCOVA, $\mathrm{F}_{(1,162)}=4.568$; $\mathrm{p}=0.034)$. However, taxonomic richness did not differ between seasons (ANCOVA, $\mathrm{F}_{(1,162)}=0.138$; $\mathrm{p}=0.710)$ (Figure 3).

Differences among abundances of functional trophic groups were observed (MANOVA, $\left.\mathrm{F}_{(4,161)}=2.886 ; \mathrm{p}=0.024\right)$. Gatherer-collectors and scrapers showed significantly higher abundances in E. grandis (Tukey test, $\mathrm{p}<0.001$ ). A difference was observed between seasonal periods (MANOVA, $\left.\mathrm{F}_{(4,161)}=2.981 ; \mathrm{p}=0.0207\right)$, determined by the high abundance of filterer-collectors and predators
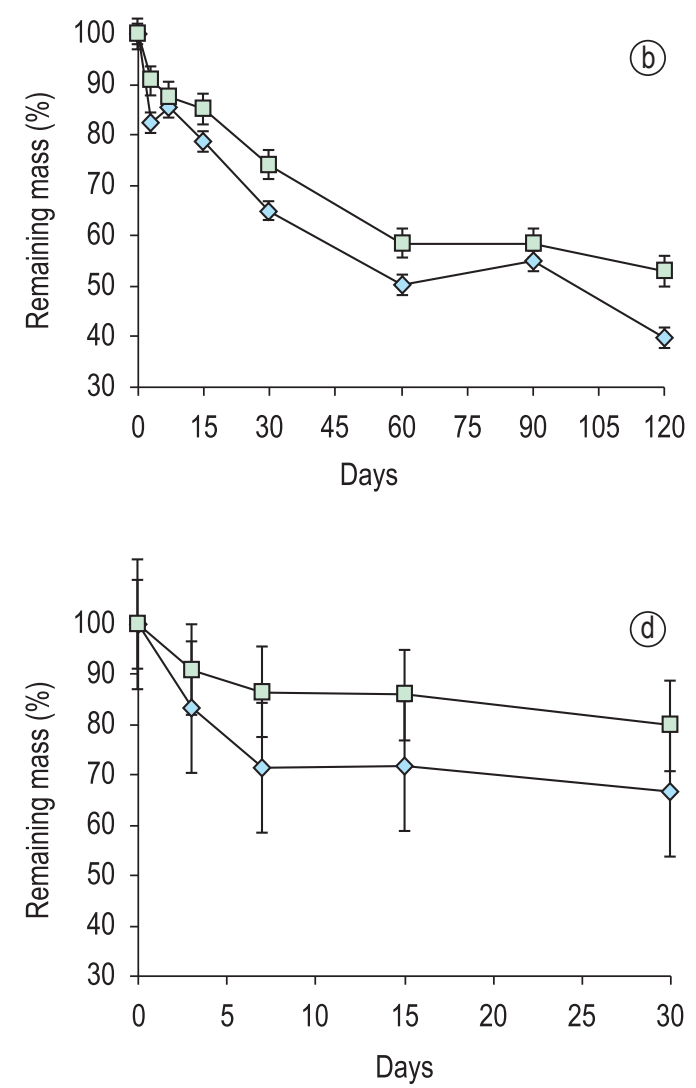

Figure 2. Percentage of ash free dry mass (mean \pm SE) of E. grandis (diamond) and H. glandulosa (square) in the Aguapé ( $\mathrm{a}$ and b) and Barra lakes ( $\mathrm{c}$ and d), during the rain (b and d) and the dry seasons (a and c). 


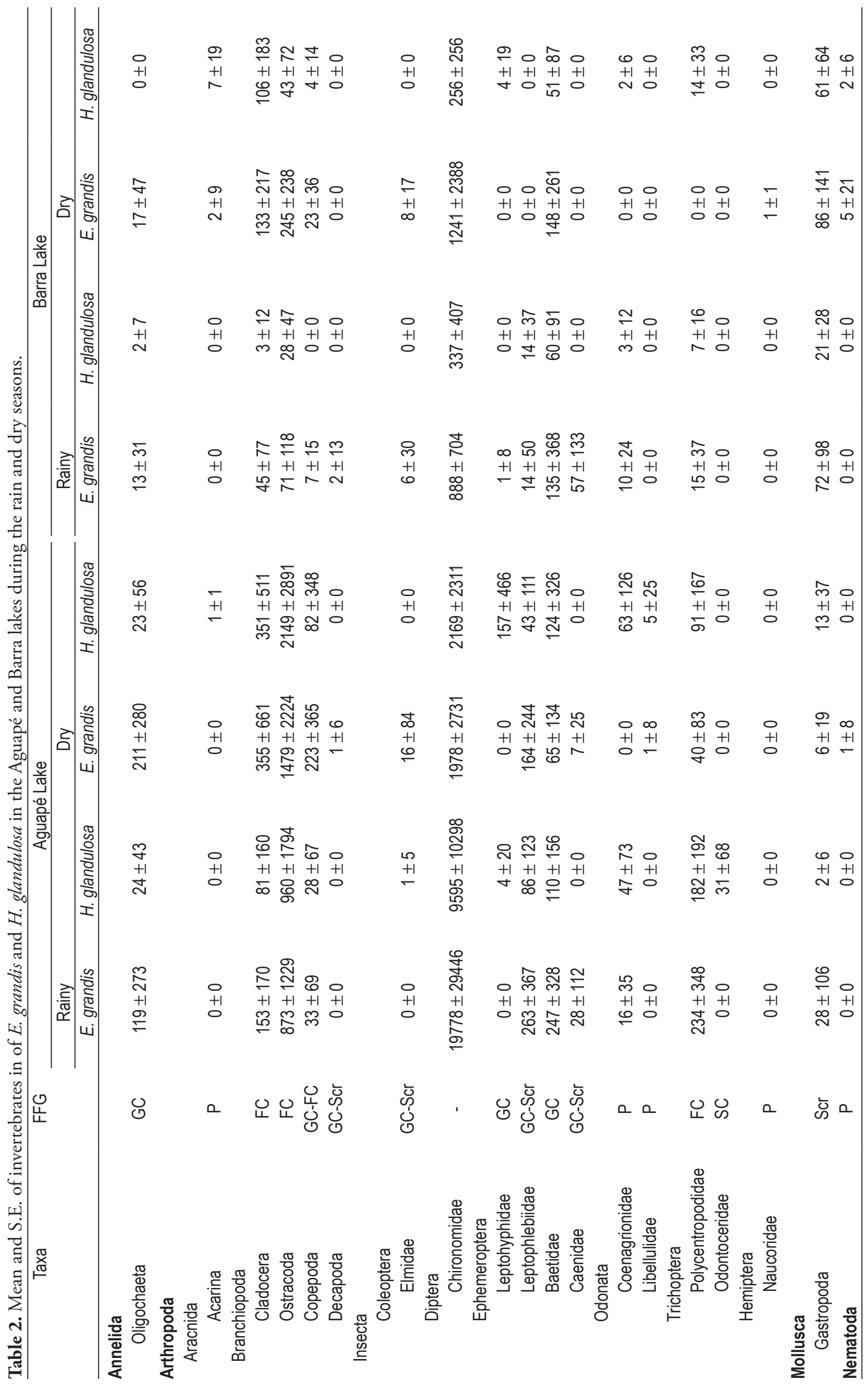



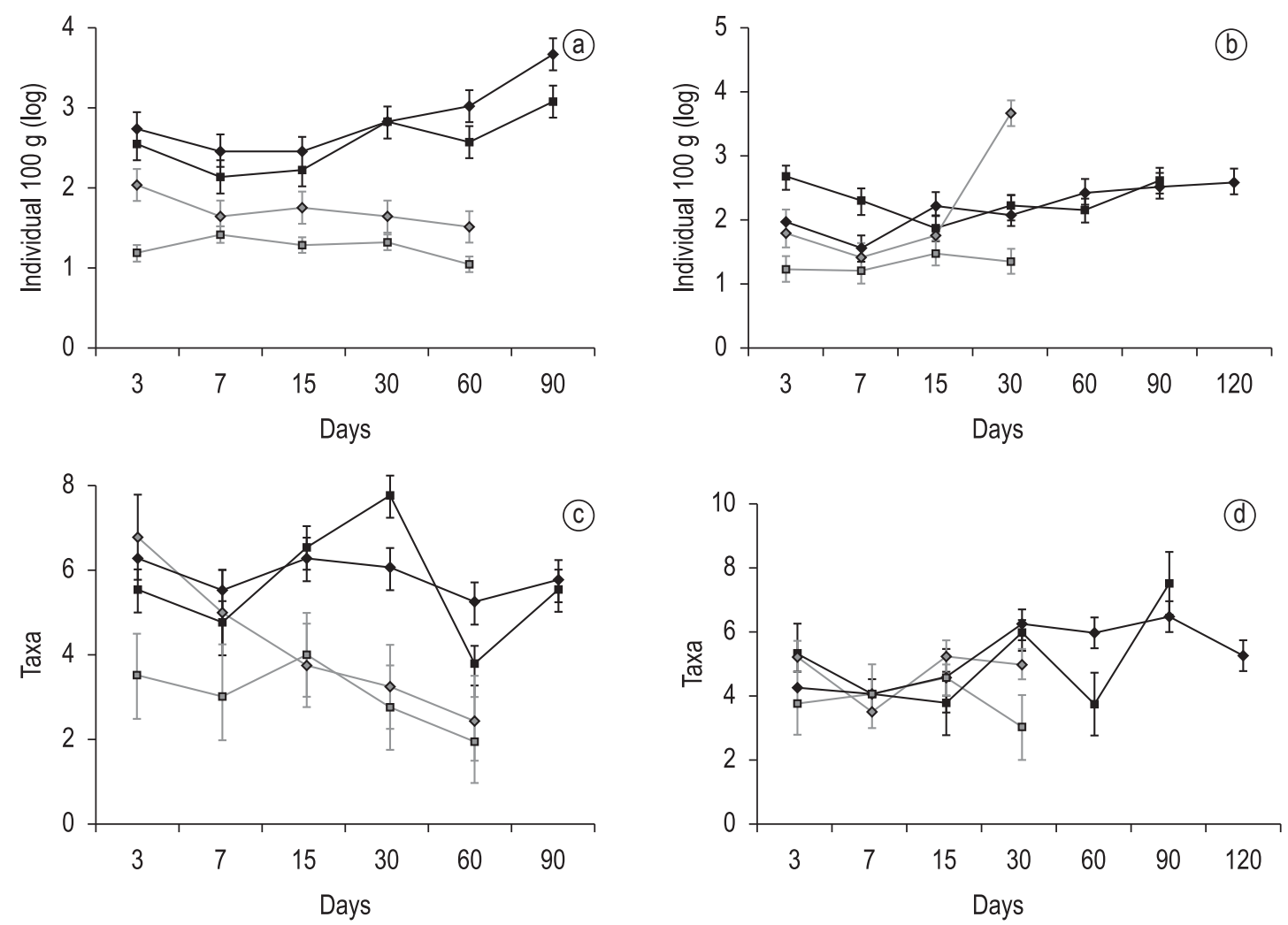

Figure 3. Abundance ( $a$ and $b$; mean $\pm S E$ ) and taxonomic richness ( $c$ and d; median $\pm S E$ ) of invertebrates in of E. grandis (diamond) and H. glandulosa (square) in the Aguapé (black line) and Barra lakes (grey line) during the rain $(\mathrm{a}$ and $\mathrm{c})$ and dry seasons $(\mathrm{b}$ and $\mathrm{d})$.

during the dry period (Tukey test, $\mathrm{p}<0.001$ ) (Figure 4).

\section{Discussion}

\subsection{Leaf breakdown}

The estimated decay rates for the two species is considered intermediate $\left(0.010>\mathrm{k}>0.005 \mathrm{day}^{-1}\right)$, in accordance with the classification proposed by Petersen and Cummins (1974) for temperate streams but It also used successfully in tropical streams (Gonçalves Jr. et al., 2006a, 2007; Moretti et al., 2007b). The faster decay rate of the E. grandis leaves can be explained by the chemical composition of the detritus (Meentemeyer, 1978; Gallardo and Merino, 1993; Aerts, 1997), because the smaller the quantity of refractory compounds (lignin and hemicelluloses), the more rapid is the weight loss (Ostrofsky, 1997). According to Gessner and Chauvet (2002) and Moretti et al. (2007a), studies on leaf breakdown should be directed toward understanding the relationship between the chemical composition of the detritus and its degradation rate. For instance, detritus composed of smaller amounts of complex molecules (such as lignin and hemicelluloses) is preferred by the aquatic microbial and invertebrate communities, and consequently their decomposition tends to be faster (Tanaka, 1991; Panhota et al., 2006). The rapid weight loss observed for detritus on the third day of incubation can be attributed to the metabolism of labile molecules (Tanaka, 1991) and/or their leaching (molecules such as proteins, carbohydrates and lipids) (Brum and Esteves, 2001a, b; Panhota et al., 2006).

Some studies have indicated that seasonal variation can influence the decomposition process through modifications in the concentrations of dissolved oxygen, conductivity, nutrient concentration, temperature, and $\mathrm{pH}$ in the water (Merrit and Cummins, 1996; Maamri et al., 1997; Garnett et al., 2000). The decay rates of both species were faster during the rainy period (summer), which is probably related to the higher temperatures (as also reported by Costantini et al., 2003 for Lake Titicaca), electrical conductivity (which reflects the amount of ions in the water), and dissolved oxygen content, parameters that act to increase the metabolism of decomposer organisms (Swan and Palmer, 2004). In the summer, an increase of few degrees in the 

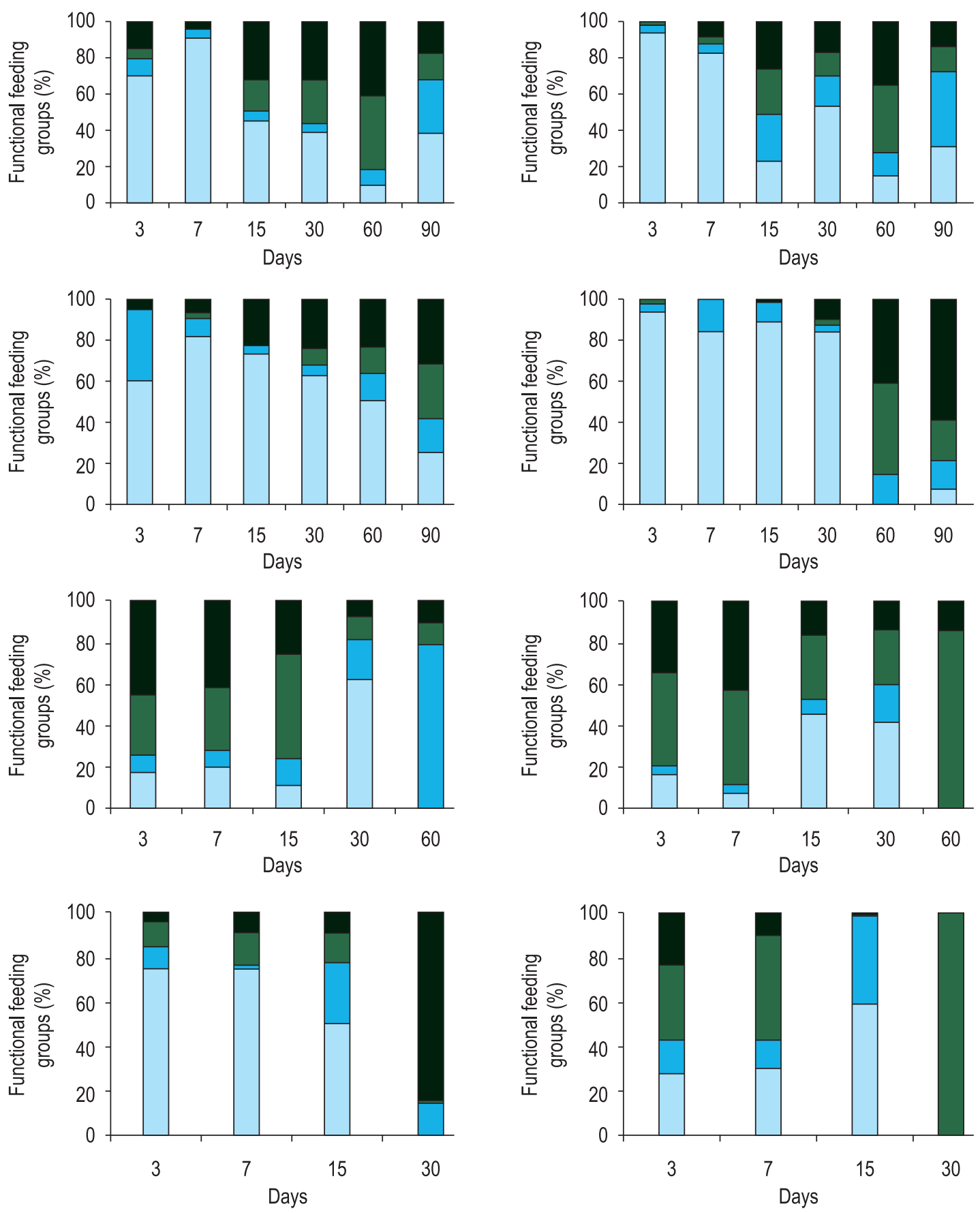

$\square \mathrm{FC} \square \mathrm{P} \square \mathrm{SC} \square \mathrm{GC}$

Figure 4. Percentage of functional feeding groups during leaf breakdown of Eucalyptus grandis (a, c, e and g) and Hirtella glandulosa (b, d, f and h) during the rain ( $, \mathrm{b}, \mathrm{e}$ and $\mathrm{f}$ ) and dry seasons (c, d, g and h). Above: Aguapé Lake; below: Barra Lake. $\mathrm{P}=$ Predators, $\mathrm{FC}=$ Filtering-collectors-, $\mathrm{GC}=$ Gathering-collectors, $\mathrm{S}=$ Shredders, Scr $=$ Scrapers.

temperature is enough to raise the metabolic activity of decomposer communities (Suberkropp and Chauvet, 1995; Gulis and Suberkropp, 2003), accelerating the decomposition process in tropical and temperate lakes, because they allowed an increase in the activity of the aquatic communities
(Carpenter and Adams, 1979; Webster and Benfield, 1986; Irons et al., 1994). These results confirmed the second hypothesis, that rates of decomposition will be higher during the rainy season, and corroborated the importance of water characteristics for the litter decomposition process. 


\subsection{Invertebrates}

Chironomidae (Diptera) was the most abundant taxon associated with both species of leaves. Similar results were obtained by Rosemond et al. (1998) in an experiment in the Costa Rica, where Chironomidae constituted $83 \%$ of the invertebrate community in a tropical stream. Chironomidae constitute a fundamental link in many food webs, feeding on planktonic and periphytic algae and being consumed by other macroinvertebrates, fish, and birds (Nolte, 1986). According to Burki et al. (1978), Chironomidae can develop resistance or can adapt physiologically and behaviorally to diverse environmental conditions. This explains their high densities in this lacustrine system. However, Chironomidae have high species diversity (with many species still undescribed in Brazil) and a generalist trophic strategy that makes their trophic classification difficult (Gonçalves Jr. et al., 2003; Callisto et al., 2007). In this study, their trophic position among functional groups in the invertebrate community was not considered, but their importance for detritus degradation cannot be disregarded.

The presence or absence of aquatic invertebrates is the result of their interaction with the habitat, mainly with the physical and chemical conditions that characterize it, and the availability of food (Merrit and Cummins, 1996; Bueno et al., 2003). Even though leaves of $E$. grandis decomposed more rapidly than $H$. glandulosa in seasonal periods, the difference in invertebrate density and richness was not significant, showing that the nutritional quality of the detritus did not influence the structure of the invertebrate community. These results indicated that E. grandis had no negative effects on the invertebrate community, thus rejecting the first hypothesis of this study. Probably the invertebrates are adapted to exploit this exotic leaf detritus, because there are many species of the family Myrtaceae in the Atlantic Rain forest. Despite of higher concentration of secondary compounds in leaves of Eucalyptus spp. (Majer and Recher, 1999), these compounds are lost faster during leaching process in the initial phase of decomposition. We believed that both explanations could be considered together to minimize the negative effects of eucalyptus leaves in tropical invertebrates' colonization when we compare with native leaves species.

Seasonal variation is another factor that influences trophic structure, by altering the physical and chemical characteristics of the water (such as water temperature, electrical conductivity, $\mathrm{pH}$, total alkalinity, and dissolved oxygen) and the rainfall dynamics, which increase the amount of nutrients and organic matter that enter the system during the summer (Hynes, 1970). These changes differentiate the structure and abundance of functional trophic groups between the rainy and dry seasons. A high relative abundance of filterer-collectors and predators during the dry season was described by Pope et al. (1996), and was observed during this study. During the rainy period, the functional trophic groups with higher relative abundances were the gatherer-collectors and the scrapers. The higher relative abundances of scrapers corresponded to the higher decomposition rates observed during the rainy period for E. grandis detritus. The trophic functional groups and density were sensitive to seasonality, confirming the second hypothesis of this study.

Shredders, the most important functional trophic group in the process of decomposition of plant detritus (Graça, 2001), were not found, suggesting that other factors (temperature, seasonality, and chemical composition of the plant detritus) were determining the decomposition rates. Considering the absence of shredders observed during this study, and also by Gonçalves Jr. et al. (2006a, b; 2007), some studies have demonstrated that the ecological niche unoccupied by shredders could be filled by Gastropoda, which scrape the substrate using their radulae to obtain food, which fragments the leaf detritus and accelerates its decomposition (Cherguei and Pattee, 1991; Maamri et al., 1997; Casas and Gessner, 1999). However, few studies in tropical regions have dealt with this question (Hurlbert et al., 1981; Lopretto and Tell, 1995). The high density of Gastropoda and the high temperatures in Barra Lake may explain its higher decomposition coefficient, even though Aguapé Lake had a higher invertebrate density, electrical conductivity, and total alkalinity (measurements that may indicate higher nutrient concentrations in the water).

In general, our data showed that E. grandis presented higher decomposition rates, and invertebrates did not encounter major difficulties in colonizing this exotic detritus, compared to the native detritus ( $H$. glandulosa), we found not difference found in densities and richness. Higher decay rates and invertebrate densities were observed in the rainy season, suggesting that the temperature increase and the input of nutrients and organic matter (provided by the rainfall) favor the intensification of this process. A large gap in knowledge yet to be investigated is the role of the microbial community in this process. 


\section{Acknowledgements}

Renan de Souza Rezende and Paula Silva Magalhães received scholarships from Fundação de Amparo a Pesquisa de Minas Gerais (FAPEMIG).

\section{References}

AERTS, R., 1997. Climate, leaf litter chemistry and leaf litter decomposition in terrestrial ecosystems: a triangular relationship. Oikos, vol. 79, no. 3, p. 439-449.

BENFIELD, EF., 1997. Comparison of litterfall input to streams: stream organic matter budgets. Journal of the North American Benthological Society, vol. 16, no. 1, p. 104-108.

BOHMAN, IM. and HERRMANN, J., 2006. The timing of winter-growing shredder species and leaf litter turnover rate in an oligotrophic lake, SE Sweden. Hydrobiologia, vol. 556, no. 1, p. 99-108.

BRUM, PR. and ESTEVES, FA., 2001a. Dry weight loss and chemical changes in the detritus of three tropical aquatic macrophyte species (Eleocharis interstincta, Nymphea ampla and Potamogeton stenostachys) during decomposition. Acta Limnologica Brasiliensia, vol. 13 , no. 1 , p. 61-73.

BRUM, PR. and ESTEVES, FA., 2001b. Changes in abundance and biomass of the attached bacterial community throughout the decomposition of three species of aquatic macrophytes. Oecologia Brasiliensis, vol. 9, no. 1, p. 77-96.

BUENO, APA., BOND-BUCKUP, G. and FERREIRA, DPB., 2003. Community structure of benthic invertebrates in two watercourses in Rio Grande do Sul State, southern Brazil. Revista Brasileira de Zoologia, vol. 20, no. 1, p. 45-66.

BURKI, E., ROTHEN, R. and SCHOLL, A., 1978. Koexstenz von zwei cytolgisch verschiedenen Populationen der zuckmucke Chironomus plumosos im Murtensee. Revisit Suisse Zoology, vol. 85, no. 2, p. 625-634.

CALLISTO, M., GONÇALVES JUNIOR, JF. and GRAÇA, MAS., 2007. Leaf litter as a possible food source for chironomids in headwater streams. Revista Brasileira de Zoologia, vol. 24, no. 2, p. 442-448.

CANHOTO, C. and GRAÇA, MAS. 1992. Importância das folhas de eucalypto na alimentaçáo de detritívoros aquáticos em ribeiros da zona centro de Portugal. In Actas do 5 Congresso Ibérico de Entomologia. Zamora. p. 473-482. (vol. 1)

CANHOTO, C. and GRAÇA, MAS., 1995. Food value of introduced eucalypt leaves for a Mediterranean stream detritivore: Tipula lateralis. Freshwater Biology, vol. 34, no. 2, p. 209-214.

CARPENTER, SR. and ADAMS, MS., 1979. Effects of nutrients and temperature on decomposition of Myriophyllum spicatum L. in a hardwater eutrophic lake. Limnology and Oceanography, vol. 24, no. 3, p. 520-528.

CASAS, JJ. and GESSNER, MO., 1999. Leaf litter breakdown in a mediterranean stream characterised by travertine precipitation. Freshwater Biology, vol. 41, no. 4, p. 781-793.

CHERGUI, H. and PATTEE, E., 1991. An experimental study of the breakdown of submerged leaves by hyphomycetes and invertebrates in Maroccos. Freshwater Biology, vol. 26, no. 1, p. 97-110.

COSTANTINI, ML., SABETTA, L., MANCINELLI, G. and ROSSI, L., 2003. Spatial variability of the decomposition rate of Schoenoplectus tatora in a polluted area of Lake Titicaca. Rome: University of Rome "La Sapienza”. 148 p.

CUMMINS, KW., WILZBACH, MA., GATES, DM., PERRY, JB. and TALLIAFERRO, WB., 1989. Shredders and riparian vegetation. BioScience, vol. 39, no. 1, p. 24-30.

DOBSON, M., MORGANA, A., MATHOOKO, JM. and NDEGWA, FK., 2002. Detritivores in Kenian highland strem: more evidence for the paucity of shedders in the tropics? Freshwater Biology, vol. 47, no. 5, p. 909-919.

GALLARDO, A. and MERINO, J., 1993. Leaf decomposition in two Mediterranean ecosystems of southwest Spain: influence of substrate quality. Ecology, vol. 74, no. 1, p. 152-161.

GARNETT, H., BÄRLOCHER, F. and GIBERSON, D., 2000. Aquatic hyphomicetes in Catamaran Brook: colonization dynamics, seasonal patterns, and logging effects. Mycologia, vol. 92, no. 1, p. 29-41.

GESSNER, MO., CHAUVET, E. and DOBSON, M., 1999. A perspective on leaf litter reakdown in streams. Oikos, vol. 85, no. 2, p. 377-384.

GESSNER, MO. and CHAUVET, E., 2002. A case for using litter breakdown to assess functional stream integrity. Journal of Applied Ecology, vol. 12, no. 2, p. 498-510.

GONÇALVES Jr., JF., ESTEVES, FA. and CALLISTO, M., 2003. Chironomids colonization in Nymphaea ampla L. detritus during a degradative ecological succession experiment in a Brazilian coastal lagoon. Acta Limnologica Brasiliensia, vol. 15, no. 2, p. 21-27.

GONÇALVES Jr., JF., FRANCA, JS. and CALLISTO, M., 2006a. Dynamics of allochthonous organic matter in a tropical brazilian headstream. Brazilian Archives of Biology and Technology, vol. 49, no. 6, p. 967-973.

GONÇALVES Jr., JF., GRAÇA, MAS. and CALLISTO, M., 2006b. Leaf-litter breakdown in 3 streams in temperate, Mediterranean, and tropical Cerrado climates. Journal of the North American Benthological Society, vol. 25, no. 2, p. 344-355. 
GONÇALVES Jr., JF., GRAÇA, MAS. and CALLISTO, M., 2007. Litter decomposition in a Cerrado savannah stream is retarded by leaf toughness, low water nutrient levels and lack of shredders. Freshwater Biology, vol. 52, no. 8, p. 1440-1451.

GRAÇA, MAS., 2001. The role of invertebrates on leaf litter decomposition in stream-a Review. International Review Hydrobiologie, vol. 86, no. 4-5, p. 383-393.

GRAÇA, MAS., POZO, J., CANHOTO, C. and ELOSEGY, A., 2002. Effects of eucalyptus plantations on detritus, decomposers, and detritivores in streams. The Scientific World, vol. 2, p. 1173-1185.

GULIS, V. and SUBERKROPP, K., 2003. Interactions between stream fungi and bacteria associated with decomposing leaf litter ad different leavels os nutrient availability. Aquatic Microbial Ecology, vol. 30, no. 2, p. 149-157.

HURLBERT, SH., RODRIGUEZ, G. and SANTOS, ND., 1981. Aquatic Biota of Tropical South America. San Diego: San Diego State University. 323 p.

HYNES, HBN., 1970. The ecology of running waters England. Liverpool: Liverpool University Press. $555 \mathrm{p}$.

IRONS, JG., OSWOOD, MW., STOUT, RJ. and PRINGLE, CM., 1994. Latitudinal patterns in leaf litter breakdown: is temperature really important? Freshwater Biology, vol. 32, no. 2, p. 401-411.

JONSSON, M., MALMQVIST, B. and HOFFSTEN, P., 2001. Leaf litter breakdown rates in boreal strem: does sherdder especies richness matter? Freshwater Biology, vol. 46, no. 2, p. 161-171.

LOPRETTO, EC. and TELL, G., 1995. Ecosistemas de aguas continentales: metodologias para su estudio. La Plata: Ediciones Sur. 1401 p. (3 vol.)

LOUZADA, JNC., 1997. Litter decomposition in semidecidous florest and Eucalyptus ssp. crop in Brazil: a comparison. Forest Ecology and Management, vol. 94, no. 1-3, p. 31-36.

MAJER, JD. and RECHER, HF., 1999. Are Eucalypts Brazil's friend or foe? An entomological viewpoint. Anais da Sociedade Entomológica do Brasil, vol. 28, no. 2, p. 185-200.

MAAMRI, A., CHERGUI, H. and PATTEE, E., 1997. Leaf litter processing in a temporary northeasten Marrocan river. Archiv für Hydrobiologie, vol. 140, no. 4, p. 513-531.

MEENTEMEYER, V., 1978. Macroclimate and lignin control of litter decomposition rates. Ecology, vol. 59, no. 3, p. 465-472.

MERRITT, RW. and CUMMINS, KW., 1996. An introduction to the aquatic insects of North America. 3 ed. Iowa: Kendall Hunt Publishing Company. $862 \mathrm{p}$.

MORETTI, MS., GONÇALVES Jr., JF., and CALLISTO, M., 2007a. Leaf breakdown in two tropical streams:
Differences between single and mixed species packs. Limnologica, vol. 37, p. 250-258.

MORETTI, MS., GONÇALVES Jr., JF., LIGEIRO, R. and CALLISTO, M., 2007b. Invertebrates colonization on native trees leaves in a neotropical stream (Brazil). International Review Hydrobiologie, vol. 92, no. 2, p. 199-210.

NOLTE, U., 1986. Erstbesiedlung kunstlicher kleingewasser und primare Sukzession des Makrozoobenthos unter besonderer Berucksichtigung der Chironomidae (Diptera) - Feldexperimente in Zentralamazonien. Göttingen: Universität Göttingen. [Tese de Doutorado]

OSTROFSKY, ML., 1997. Relationship between chemical characteristics of autumn-shed leaves and aquatic processing rates. Journal of the North American Benthological Society, vol. 16, no. 4, p. 750-759.

PANHOTA, RS., BIANCHINI Jr., I. and VIEIRA, AAH., 2007. Glucose uptake and extracellular polysaccharides (EPS) produced by bacterioplankton from an eutrophic tropical reservoir (Barra Bonita, SP Brazil). Hydrobiologia, vol. 583, no. 1, p. 223-230.

PÉREZ, GR., 1988. Guia para el estudio de los macroinvertebrados acuáticos del Departamento de Antioquia. Bogotá: Universidad de Antioquia. $132 \mathrm{p}$.

PETERSEN, RC. and CUMMINS, KW., 1974. Leaf pack processing in a woodland stream. Freshwater Biology, vol. 4, no. 4, p. 343-368.

PETRUCIO, MM. and BARBOSA, FAR., 2004. Diel variations of phytoplankton and bacterioplankton production rates in four tropical lakes in the middle Rio Doce Basin (Southeastern Brazil). Hydrobiologia, vol. 513, no. 1-3, p. 71-76.

PETRUCIO, MM., BARBOSA, FAR. and FURTADO, ALS., 2006. Bacterioplankton and Phytoplankton Production in seven Lakes in the Middle Rio Doce Basin, South-East Brazil. Limnologica, vol. 36, no. 3, p. 192-203.

PIMENTEL, D., MCNAIR, S., WIGHTMAN, J., SIMMONDS, C., O'CONNELL, C., WONG, E., RUSSEL, L., ZERN, J., AQUINO, T. and TSOMONDO, T., 2001. Economic and environmental threat of alien plant, animal, and microbe invasions. Agriculture, Ecosystems and Environment, vol. 84, no. 1, p. 1-20.

POPE, RJ., 1996. Colonization of leaf litter by aquatic invertebrates in the littoral zone of an oligotrophic lake. Guelph: University of Guelph. [Dissertação de Mestrado]

ROSEMOND, AD., PRINGLE, CM. and RAMÍREZ, A., 1998. Macroconsumer effects on insect detritivores and detritus processing in and a tropical stream. Freshwater Biology, vol. 39, no. 3, p. 515-523.

SUBERKROPP, K. and CHAUVET, E., 1995. Regulation of leaf breakdown by fungi in stream: 
influences of water chemistry. Ecology, vol. 76, no. 5, p. 720-727.

SWAN, CM. and PALMER, MA., 2004. Leaf diversity alters litter breakdown in a Piedmont stream. Journal of the North American Benthological Society, vol. 23, no. 1 , p. 15-28.

TANAKA, Y., 1991. Microbial decomposition of reed (Phragmites communis) leaves in a saline lake. Hydrobiologia, vol. 220, no. 2, p. 119-129.

WALLACE, JB. and WEBSTER, JR., 1996. The role of macroinvertebrates in stream ecosystem function. Annual Review of Entomology, vol. 41, p. 115-139.
WALLACE, JB., EGGERT, SL., MEYER, JL. and WEBSTER, JR., 1997. Multiple trophic levels of a forest stream linked to terrestrial litter inputs. Science, vol. 277, no. 5322, p. 102-104.

WEBSTER, JR. and BENFIELD, EF, 1986. Vascular plant breakdown in freshwater ecosystems. Annual Review of Ecology and Systematics, vol. 17, p. 567-594.

ZAR, JH., 1996. Bioestatistical analysis. New Jersey: Prentice Hall. 663 p.

Received: 17 September 2009 Accepted: 18 March 2010 